\title{
Pengaruh Holding Time Annealing terhadap Perubahan Mikrostruktur Baja Struktur S690QL dan S235JR
}

\author{
Ari Wibowo*, Hanifah Widiastuti", Nurul Laili Arifin*, Nugroho Pratomo Aryanto* \\ *Batam Polytechnics \\ Mechanical Engineering Study Program \\ Jl. Ahmad Yani, Batam Centre, Batam 29461, Indonesia \\ E-mail: ariwibowo@polibatam.ac.id, hanifah@polibatam.ac.id, laili@polibatam.ac.id, \\ nugroho@polibatam.ac
}

\begin{abstract}
Abstrak
Baja struktur S690 dan S235JR banyak digunakan pada peralatan berat untuk struktur kerangka utama. Pada umumnya, proses fabrikasi peralatan berat selalu melibatkan proses pengelasan yang berpotensi mengubah sifat mekanis material. Oleh karena itu, pada proses fabrikasi yang melibatkan kedua baja tersebut, dilakukan proses perlakuan panas setelah pengelasan untuk memodifikasi sifat mekanisnya. Proses perlakukan panas ini dilakukan terutama untuk menghilangkan tegangan sisa dan menurunkan kegetasan melalui proses annealing. Dalam penelitian ini, annealing dilakukan pada kedua baja tersebut untuk melihat pengaruh proses perlakuan panas pada kekerasan dan struktur mikro material. Pada kedua baja tersebut dilakukan proses annealing dengan suhu $760^{\circ} \mathrm{C}$, holding time 2, 4, 6, 8, dan 10 jam serta laju pendinginan $20^{\circ} \mathrm{C} / \mathrm{jam}$. Setelah proses annealing, pengamatan dengan mikroskop metalurgi dilakukan untuk melihat struktur mikro akhir dilanjutkan dengan pengujian kekerasan material menggunakan metode Rockwell B. Hasil pengujian menunjukkan bahwa holding time annealing mempengaruhi fasa dan ukuran butir serta kekerasan baja S690 dan S235JR. Ukuran butir terbesar terbentuk dengan holding time 10 jam sementara kekerasan terendah juga didapatkan pada holding time 10 jam. Holding time annealing juga mempengaruhi perubahan fasa dari fine bainite menjadi ferrite dengan butir yang besar pada S690 dan menurunkan ukuran pearlite pada S235JR. Hasil pengujian juga menunjukkan bahwa holding time yang lama berpotensi menimbulkan efek dekarburisasi pada baja.
\end{abstract}

Kata kunci: Annealing, S690QL, S235JR, Struktur mikro, Kekerasan

\begin{abstract}
The S690 and S235JR structural steels are widely used in heavy equipment for the main frame structure. In general, the fabrication processes of heavy equipment involve welding processes that could change the mechanical properties of the materials. Therefore, in the fabrication process involving those steels, a heat treatment process is carried out after welding to modify the mechanical properties. The heat treatment process is conducted mainly to eliminate residual stresses and to reduce brittleness through the annealing process. In this study, annealing was carried out on the two steels to observe the effect of the heat treatment process on the hardness and microstructure of the material. The annealing process was conducted at $760^{\circ} \mathrm{C}$, holding time varied at $2,4,6,8$ and 10 hours, and a cooling rate of $20^{\circ} \mathrm{C} /$ hour. After the annealing process, observations with a metallurgical microscope were done to see the final microstructure, followed by testing material hardness using the Rockwell B method. The test results showed that the annealing holding time affected the phases and grain size as well as the hardness of the steel S690 and S235JR. The largest grain size is formed with a holding time of 10 hours while the lowest hardness is also obtained at a holding time of 10 hours. Annealing holding time also affects the phase change from fine bainite to ferrite with large grains on S690 and reduces the size of pearlite on S235JR. The test results also show that long holding time has the potential to cause a decarburization effect on steel.
\end{abstract}

Keywords: Annealing, S690QL, S235JR, Microstructure, Hardness

\section{Pendahuluan}

Baja struktur S690QL dan S235JR banyak digunakan sebagai struktur kerangka utama peralatan berat, bangunan maupun jembatan [1]. Baja tersebut memiliki komposisi karbon yang rendah namun 
memiliki kekuatan yang sangat tinggi. Klasifikasi baja tersebut masuk ke dalam golongan mild steel yang memiliki pearlite dan ferrite dengan sifat mekaniknya yang mudah diubah. Pada proses fabrikasinya, baja tersebut melalui proses perlakuan panas (heat treatment). Dalam standar EN, baja S690QL dikategorikan sebagai high strength steel (HSS) sedangkan baja S235JR dikategorikan sebagai normal strength steel (NSS). Baja S690QL memiliki yield strength minimal $690 \mathrm{MPa}$ dan karbon ekivalen (Cev) 0,65 yang merupakan produk quenching dan tempering, sedangkan baja S235JR memiliki yield strength minimal $235 \mathrm{MPa}$ dan Cev 0,35 yang merupakan produk normalizing [2]-[4]. Perlakuan panas setelah proses pengelasan/Post Weld Heat Treatment (PWHT) berupa annealing sering dilakukan pada material hasil pengelasan dengan karbon ekivalen tinggi karena kecenderungan untuk terjadinya penggetasan (embrittlement) pada baja dengan Cev tinggi sangat sering terjadi yang mengakibatkan adanya keretakan setelah pengelasan [4], [5]. Baja S690QL termasuk baja yang memiliki $\mathrm{Cev}$ tinggi $(\mathrm{Cev}>0,52)$, sehingga diperlukan perlakuan panas pada proses fabrikasi untuk menghilangkan tegangan sisa dan mengembalikan deformasi yang terjadi akibat pengelasan. Proses perlakuan panas berpotensi mengubah mikrostruktur dan kekerasan material sesuai dengan metode yang digunakan. Perubahan yang terjadi dipengaruhi oleh suhu proses, waktu penahanan (holding time), dan laju pendinginan (cooling rate). Salah satu metode PWHT yang banyak digunakan adalah annealing. Proses ini dilakukan dengan cara memanaskan material sampai suhu tinggi yang memungkinkan terjadinya rekristalisasi dan/atau transformasi fase kemudian material didinginkan secara perlahan, biasanya dibiarkan mendingin di dalam tungku. Pada penelitian ini, suhu yang digunakan merupakan suhu yang umum untuk PWHT [2],[6]. Periode holding time untuk setiap golongan material berbeda-beda sehingga waktu yang tepat perlu untuk diketahui agar karakteristik material akhir yang diinginkan sesuai dengan yang diinginkan. Oleh karena itu, perlu dilakukan pengujian mikrostruktur dan kekerasan pada baja S690QL dan S235JR setelah proses annealing dengan variasi holding time untuk mengetahui perubahan fasa dan kekerasannya.

\section{Metodologi Penelitian}

Spesimen dibuat dari plat baja S690QL dan S235JR yang dipotong dengan ukuran $15 \times 15 \times 15 \mathrm{~mm}$ menggunakan bandsaw seperti ditunjukkan pada Gambar 1. Pada specimen ini dilakukan karakterisasi komposisi kimia dari material baja S690QL dan S235JR menggunakan Optical Emission Spectroscopy (OES) untuk membandingkan apakah komposisi kimia material sesuai dengan standar spesifikasi yang disajikan pada Tabel 2.

Persiapan spesimen sebelum proses perlakuan panas dilakukan dengan cara menghaluskan dan meratakan salah satu permukaannya setelah pemotongan. Selanjutnya spesimen dipanaskan dalam tungku pada suhu $760{ }^{\circ} \mathrm{C}$ [2],[6]. Mekanisme pemanasan yang dilakukan pada penelitian ini ditunjukkan pada Gambar 2 dan Tabel 2. Heat treatment dilakukan dengan menggunakan tungku carbolite 1600 dengan pengendali kecepatan pendinginan. Annealing dilakukan dengan kecepatan pendinginan $20^{\circ} \mathrm{C} / \mathrm{jam}$ untuk semua material sampai pada suhu kamar. Waktu yang dibutuhkan untuk pendinginan dari suhu $760^{\circ} \mathrm{C}$ sampai $15^{\circ} \mathrm{C}$ sekitar 38 jam.

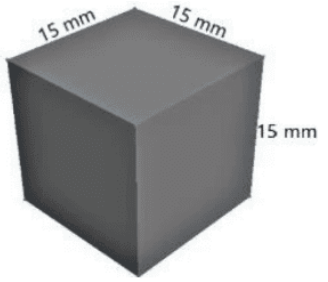

Gambar 1. Dimensi Spesimen yang Digunakan

Tabel 1. Komposisi kimia baja S690QL dan S235JR [7], [8]

\begin{tabular}{|c|c|c|c|c|c|c|c|}
\hline Grade & $\mathrm{C}$ & $\mathrm{Mn}$ & $\mathrm{Si}$ & $\mathrm{Ni}$ & $S$ & $\mathrm{Cr}$ & $\mathrm{P}$ \\
\hline $\begin{array}{l}\text { S235J } \\
R\end{array}$ & $\frac{\leq 0,1}{7}$ & $\begin{array}{l}\leq 1,4 \\
0\end{array}$ & - & - & $\begin{array}{l}\leq 0,03 \\
5\end{array}$ & & $\begin{array}{l}\leq 0,03 \\
5\end{array}$ \\
\hline $\begin{array}{l}\text { S690Q } \\
\text { L }\end{array}$ & $\leq 0,2$ & $\begin{array}{l}\leq 1,7 \\
0\end{array}$ & $\begin{array}{l}\leq 0,8 \\
0\end{array}$ & $\begin{array}{l}\leq 2, \\
0\end{array}$ & $\leq 0,01$ & $\begin{array}{l}\leq 1, \\
5\end{array}$ & $\leq 0,2$ \\
\hline
\end{tabular}

Tabel 2. Variable heat treatment

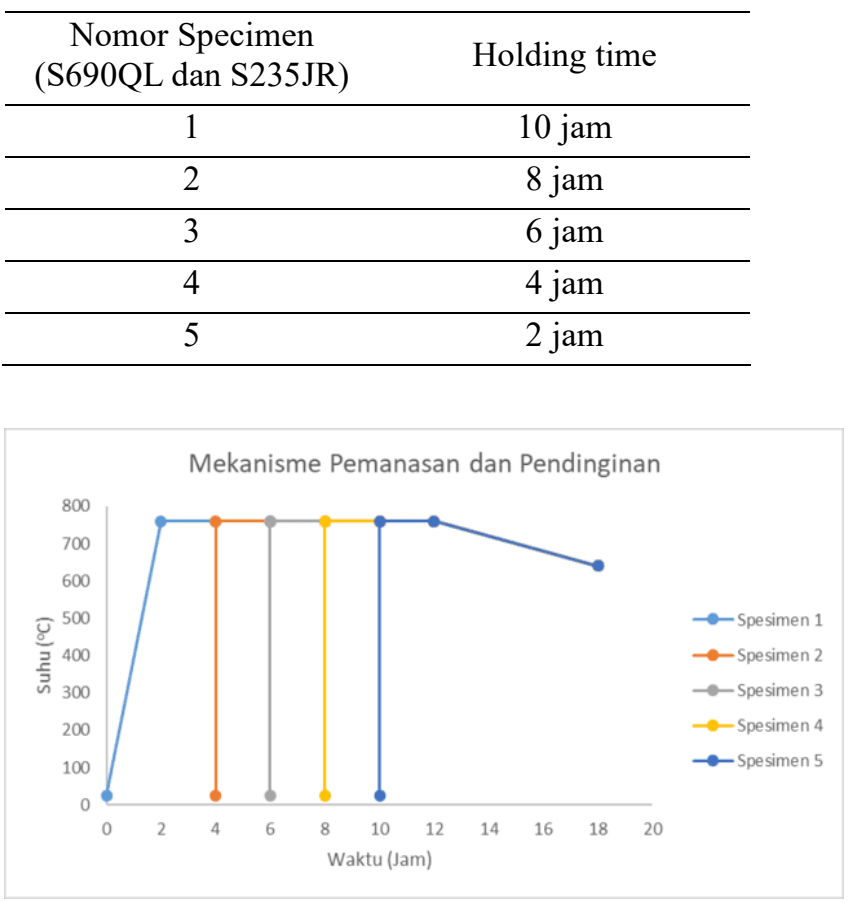

Gambar 2. Mekanisme Perlakuan Panas

Setelah proses annealing, selanjutnya specimen digerinda dengan kedalaman $5 \mathrm{~mm}$ untuk diuji kekerasan dan struktur mikronya. Hal ini dilakukan 
untuk menghindari efek dekarburisasi (hilangnya karbon dari paduan akibat reaksi dengan oksigen) karena penggunaan tungku atmosfer. Efek dekarburisasi bisa mempengaruhi perubahan kekerasan dan struktur mikro dari baja.

Pengujian kekerasan yang digunakan adalah metode Rockwell B [9]. Material dipreparasi melalui pengamplasan dengan grit 60 dan grit 800 masingmasing selama 10 menit. Pengujian kekerasan dilakukan pada material masing-masing sebanyak tiga titik.

Pengujian struktur mikro dilakukan di bagian tengah material atau pada titik yang berjarak minimal $5 \mathrm{~mm}$ dari tepi material. Preparasi pengujian struktur mikro dilakukan dengan pengamplasan material dengan grit 60, 800 dan 1200 masing-masing selama 10 menit. Setelah pengamplasan, dilakukan polishing dengan menggunakan magicsoll sebagai pengganti pasta alumina selama 5 menit. Preparasi specimen dilanjutkan dengan etching natal $(3 \% \mathrm{NaOH}+97 \%$ Ethanol) [10]. Pengamatan terhadap persentase fasefase material dan ukuran butir dilakukan dengan bantuan software open source ImageJ [11].

\section{Hasil dan Pembahasan}

Hasil pengujian spektroskopi (Tabel 3) menunjukkan bahwa material yang digunakan telah sesuai dengan standar spesifikasi seperti yang ditampilkan pada Tabel 2. Hasil pengujian struktur mikro sebelum perlakuan panas annealing ditunjukkan pada Gambar 3. Struktur mikro baja S690QL (Gambar 3a) sebelum annealing menunjukkan fase bainite [3], [4], sedangkan struktur mikro baja S235JR (Gambar 3b) sebelum annealing menunjukkan kombinasi fase ferrite dengan warna putih dan pearlite dengan warna gelap [3]. Persentase pearlite pada gambar mikro tersebut adalah $\pm 20 \%$. Pada Gambar 4, dua gambar mikro tersebut menunjukkan mikrostruktur dari baja S690QL (Gambar 4a) dan S235JR (Gambar 4b) yang mengalami perubahan akibat annealing dengan kecepatan yang sangat rendah. Gambar diambil dari permukaan baja dengan kedalaman kurang dari $50 \mu \mathrm{m}$. Kedua gambar tersebut menunjukkkan fase ferrite $100 \%$ akibat terjadinya dekarburisasi. Ukuran butir dari permukaan baja tersebut juga mengalami perubahan menjadi lebih besar dibanding dengan material awal. Diameter rata-rata ukuran butir S690QL sebesar $30 \pm 10 \mu \mathrm{m}$ sedangkan ukuran butir S235JR adalah $23+9 \mu \mathrm{m}$.

Kedalaman atau penetrasi dari dekarburisasi baja yang terjadi pada material tersebut bisa dilihat pada Gambar 5. Dekarburisasi pada baja S690QL terjadi sampai kedalaman $\pm 200 \mu \mathrm{m}$ (Gambar 5a) sedangkan pada baja S235JR sampai $\pm 400 \mu \mathrm{m}$ (Gambar 5b). Perbedaan kedalaman dekarburisasi ini disebabkan oleh komposisi karbon pada kedua baja tersebut dengan S690QL memiliki kandungan karbon lebih tinggi. Gambar mikro dekarburisasi pada Gambar 5 didapatkan pada holding time 6 jam

Tabel 3. Komposisi kimia baja S690QL dan S235JR

\begin{tabular}{llllllll}
\multicolumn{7}{c}{ hasil pengujian OES } \\
\hline Grade & $\mathrm{C}$ & $\begin{array}{l}\mathrm{M} \\
\mathrm{n}\end{array}$ & $\mathrm{Si}$ & $\mathrm{Ni}$ & $\mathrm{S}$ & $\mathrm{Cr}$ & $\mathrm{P}$ \\
\hline S235JR & $\begin{array}{l}0,1 \\
6\end{array}$ & 1,1 & 0,1 & $\begin{array}{l}0,01 \\
2\end{array}$ & 0,01 & $\begin{array}{l}0,0 \\
2\end{array}$ & $\begin{array}{l}0,0 \\
2\end{array}$ \\
\hline S690Q & $\begin{array}{l}0,1 \\
\mathrm{~L}\end{array}$ & 1,6 & $\begin{array}{l}0,6 \\
3\end{array}$ & 0,9 & $\begin{array}{l}0,00 \\
8\end{array}$ & $\begin{array}{l}0,0 \\
2\end{array}$ & 0,1 \\
\hline
\end{tabular}
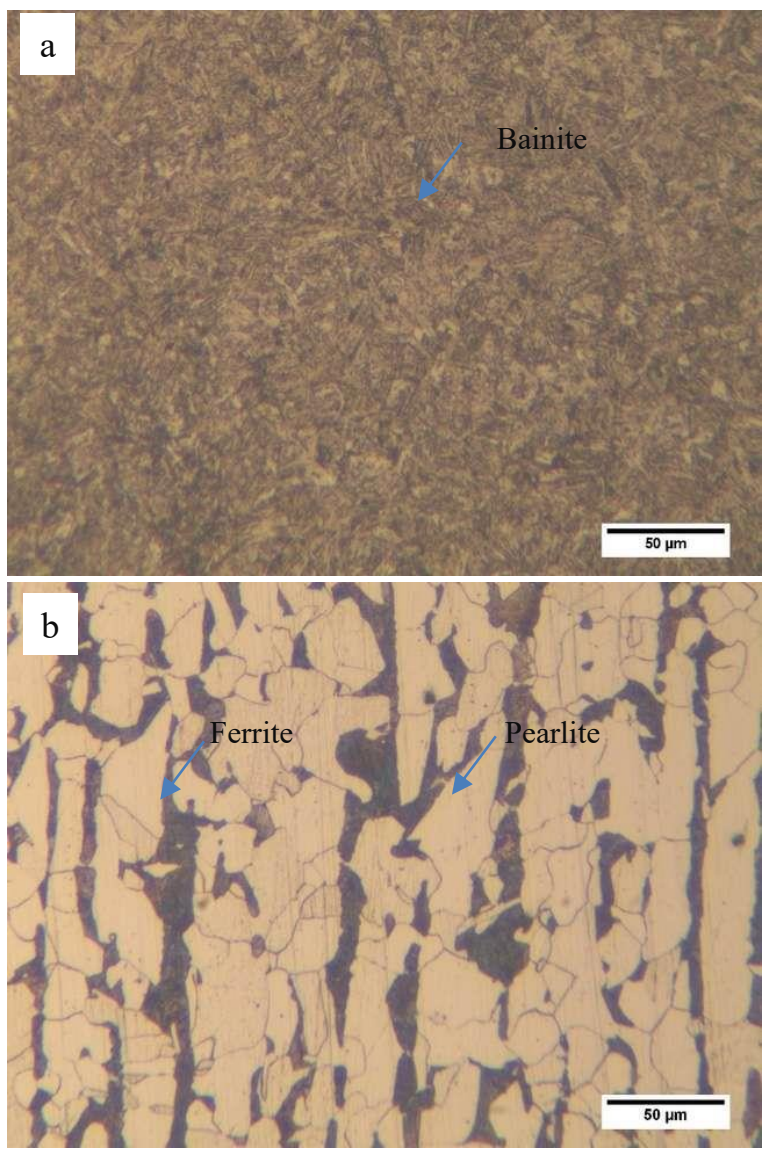

Gambar 3. Struktur mikro material asal a) S690QL, b) S235JR

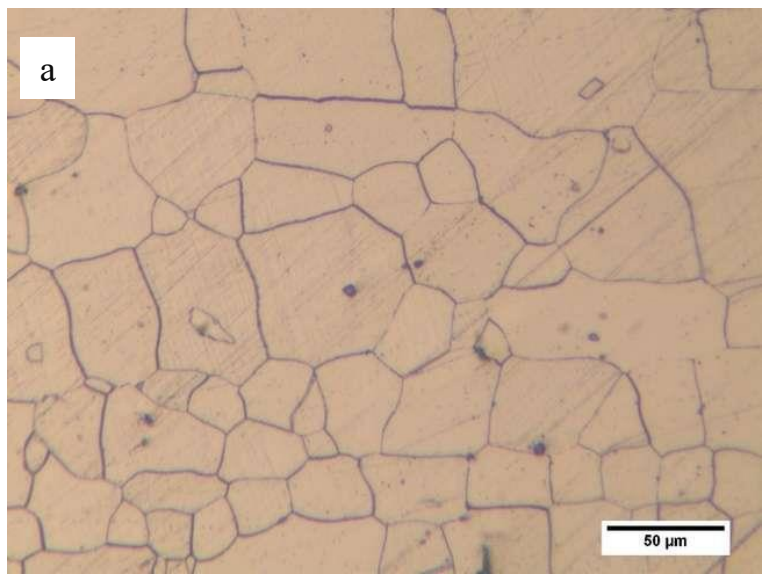




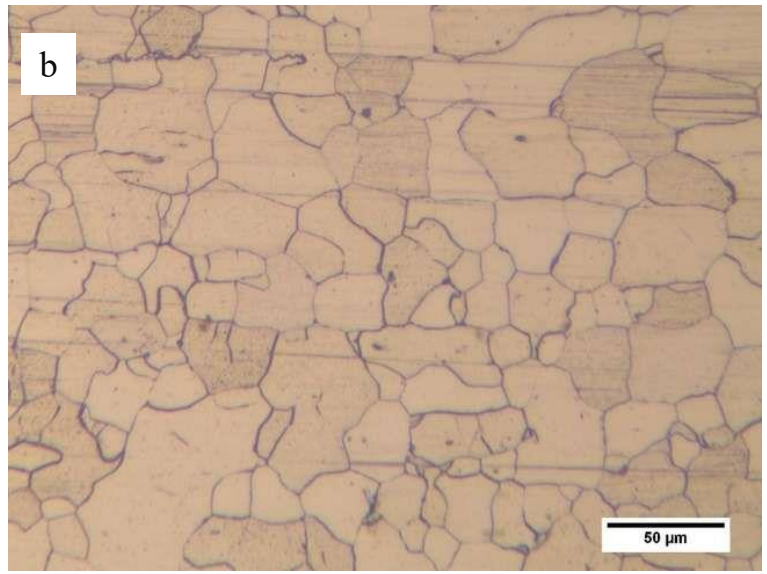

Gambar 4. Struktur mikro permukaan baja akibat dekarburisasi a) S690QL, b) S235JR
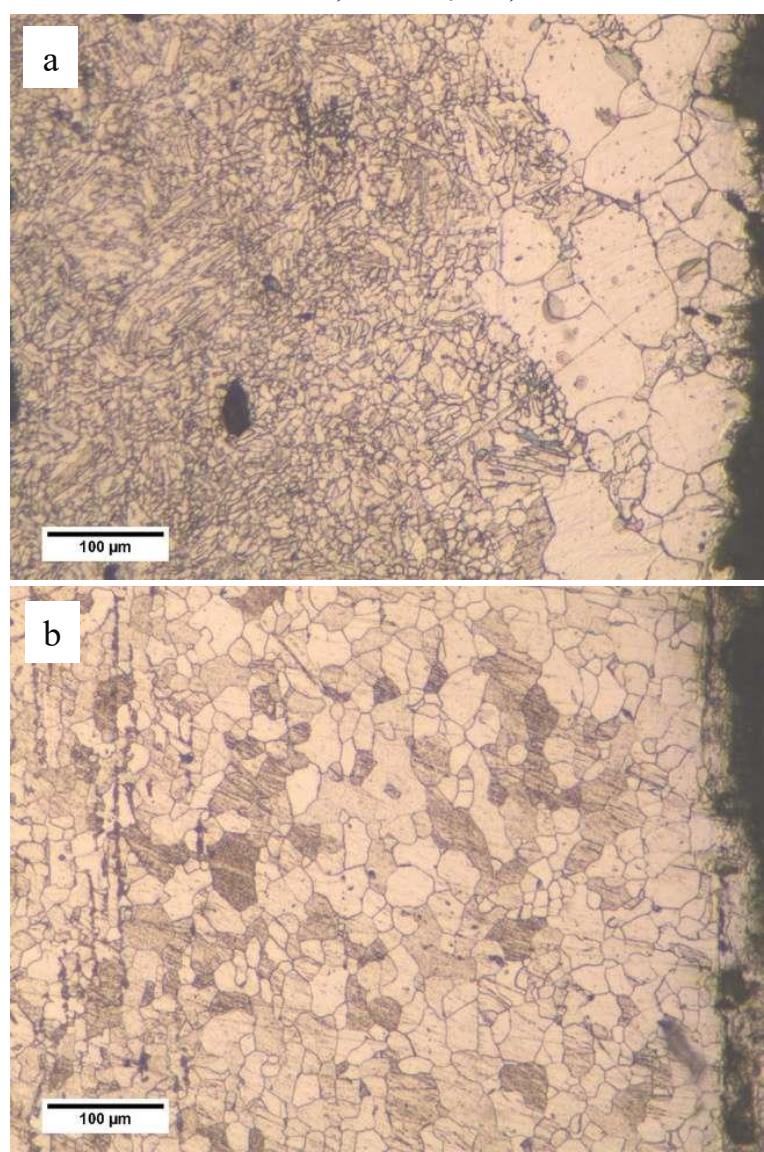

Gambar 5. Profil samping struktur mikro baja yang mengalami dekarburisasi a) S690QL, b) S235JR

Hasil pengujian struktur mikro akibat perbedaan holding time dipresentasikan pada Gambar 6 dan 7 . Dibandingkan dengan material asal pada Gambar 3a, baja S690QL mengalami peningkatan ukuran butir yang cukup signifikan, namun peningkatannya tidak bisa dikuantifikasi karena keterbatasan software. Sebagian dari fase bainite pada S690QL juga berubah menjadi ferrite dan sebagian tetap bainite [3]. Dari kedua gambar tersebut, dapat dilihat bahwa ukuran butir pada holding time 10 jam (Gambar 6a) lebih besar dibanding dengan holding time yang lain (Gambar 6b-Gambar 6e). Hal ini menunjukkan bahwa semakin lama holding time maka akan semakin besar ukuran butir yang disebabkan oleh tersedianya cukup waktu untuk butiran berkembang.
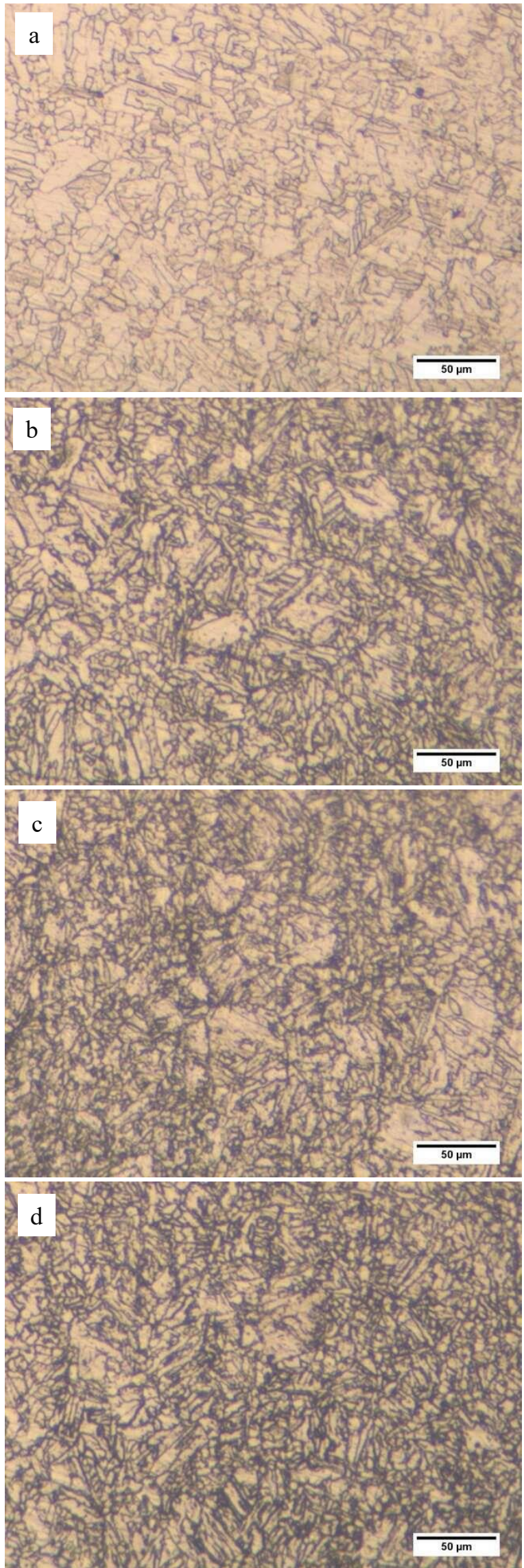


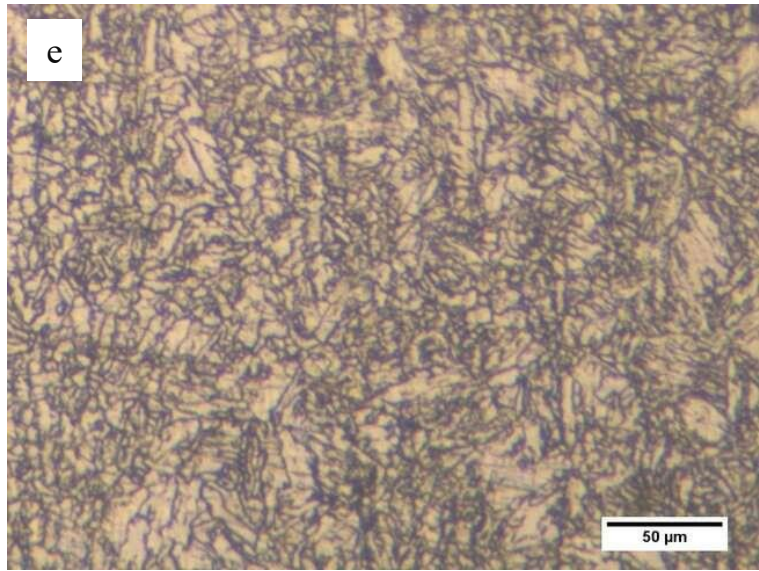

Gambar 6. Struktur mikro baja S690QL setelah annealing dengan holding time: a) 10 jam, b) 8 jam, c) 6 jam, d) 4 jam, e) 2 jam

Gambar 7 menunjukkan mikrostruktur dari baja S235JR yang mengalami perubahan. Pada gambar 7a dapat dapat dilihat bahwa holding time 10 Jam meyebabkan jumlah dan ukuran butir pearlite paling kecil di antara holding time yang lain yaitu Gambar $7 \mathrm{~b}$ untuk 8 Jam, Gambar 7c untuk 6 Jam, Gambar 7d untuk 4 jam, dan Gambar 7e untuk 2 jam. Persentase fase pearlite ditunjukkan oleh Gambar 8. Jumlah pearlite paling sedikit didapatkan pada specimen dengan holding time 10 jam yaitu sekitar $8 \%$.

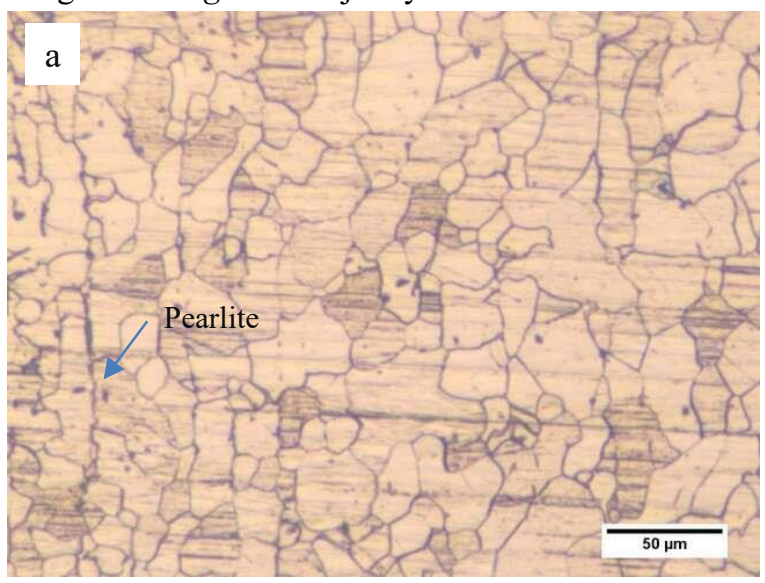

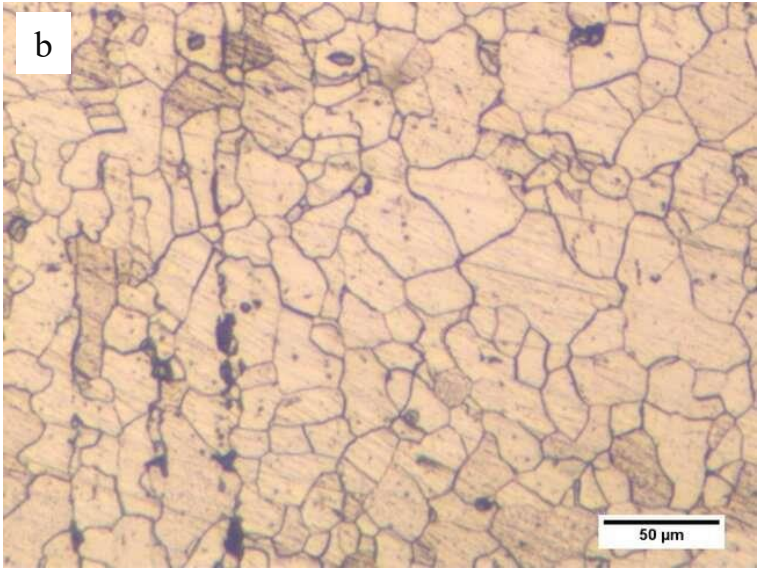
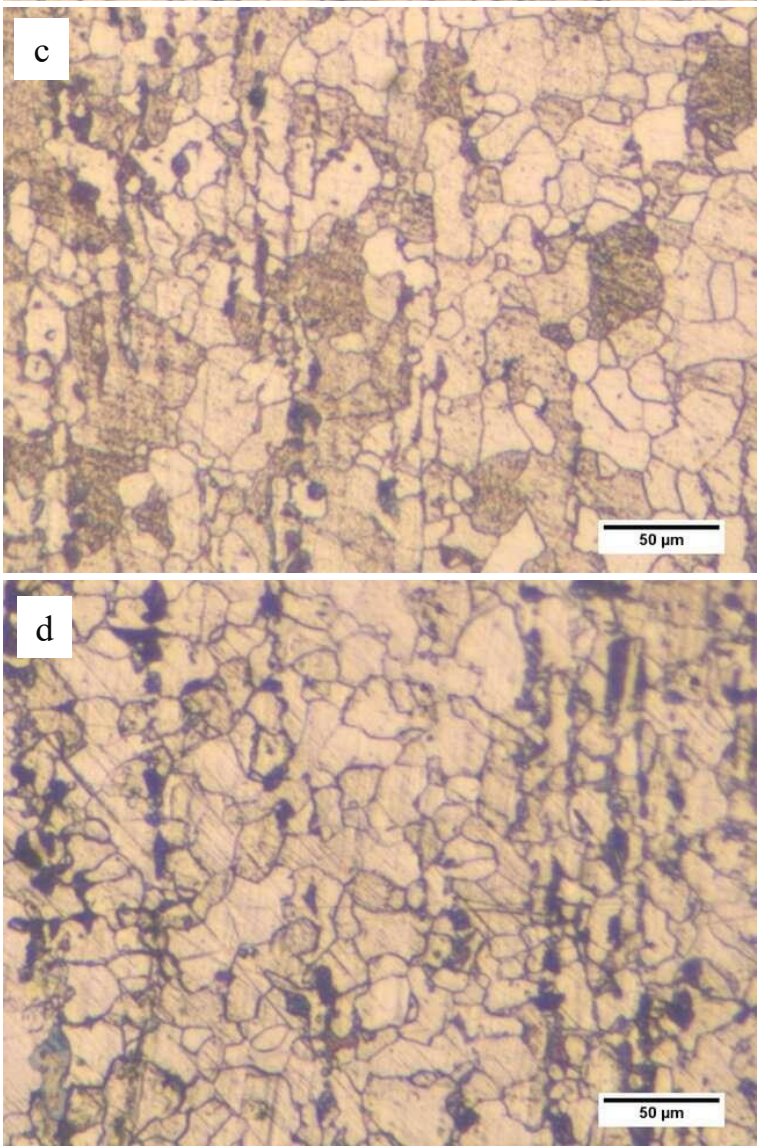

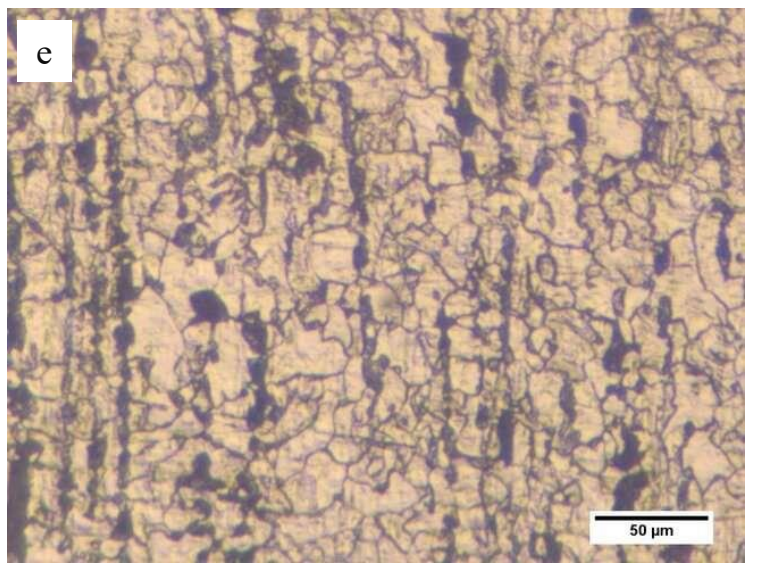

Gambar 7. Struktur mikro baja S235 setelah annealing dengan holding time: a) 10 jam, b) 8 jam, c) 6 jam, d) 4 jam, e) 2 jam 


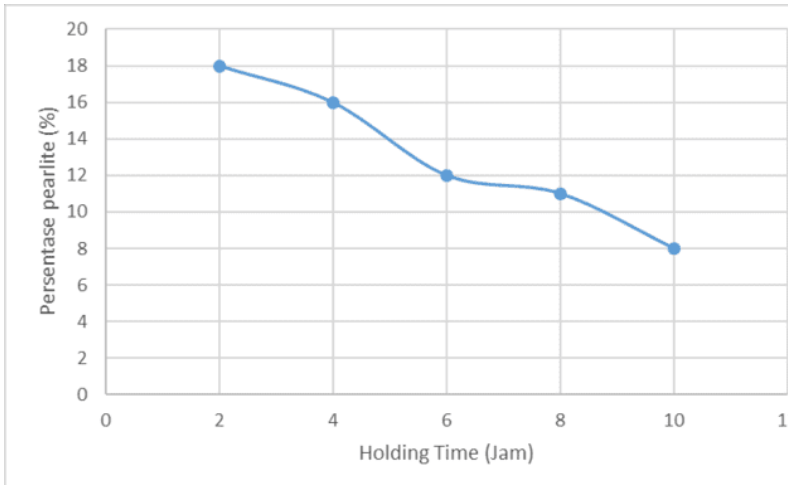

Gambar 8. Persentase pearlite terhadap holding time annealing.

Hasil pengujian kekerasan ditampilkan pada Gambar 9. Pengujian kekerasan menunjukkan bahwa terjadi penurunan kekerasan material yang cukup signifikan setelah annealing pada baja S690QL. Kekerasan baja S690QL sebelum annealing adalah $38 \mathrm{HRC}( \pm 110$ HRB) [12], sedangkan kekerasan setelah annealing paling rendah adalah $64 \mathrm{HRB}$ yang terjadi pada spesimen dengan holding time 10 jam. Penurunan kekerasan tersebut kemungkinan disebabkan oleh perubahan mikrostruktur dari fine bainite menjadi ferrite dengan ukuran butir yang lebih besar. Di sisi lain, hasil pengujian kekerasan pada baja S235JR menunjukkan perubahan kekerasan yang tidak signifikan. Baja S235JR sebelum annealing memiliki kekerasan 80 HRB sedangkan paling rendah memiliki kekerasan 65 HRB. Dari hasil ini, maka dapat diamati bahwa penurunan nilai kekerasan pada high strength steel jauh lebih besar dibanding dengan normal strength steel [13].

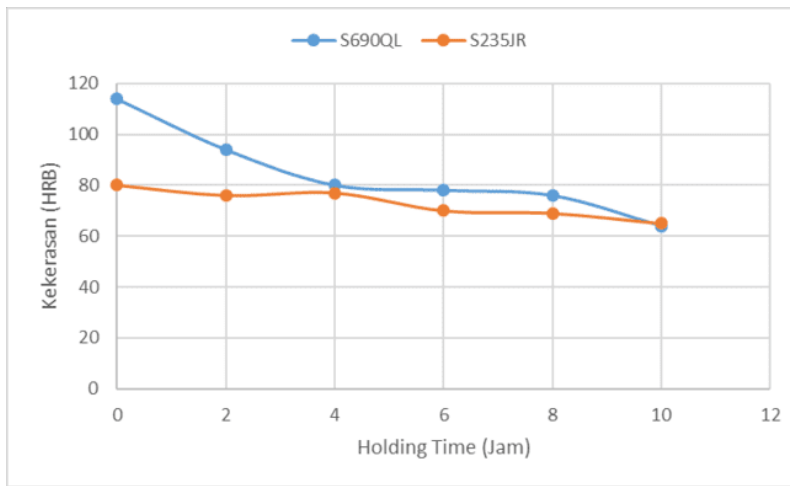

Gambar 9. Hasil pengujian kekerasan

\section{Kesimpulan}

Annealing pada baja S690QL menyebabkan terjadinya perubahan mikrostruktur dari fine bainite menjadi ferrite dengan ukuran yang lebih besar. Perubahan mikrostruktur tersebut juga diiringi oleh perubahan nilai kekerasan menjadi lebih kecil. Annealing pada baja S235JR tidak menyebabkan perubahan struktur mikro yang cukup signifikan dikarenakan material awal sebelum annealing memiliki ukuran butir yang besar. Penurunan kekerasan pada baja S690QL jauh lebih besar dibanding S235JR. Terjadi penurunan presentase pearlite pada baja S235JR. Annealing dengan kecepatan yang rendah akan menyebabkan dekarburisasi sampai pada kedalaman $\pm 200 \mu \mathrm{m}$ untuk baja S690QL dan $\pm 400 \mu \mathrm{m}$ pada baja S235JR.

\section{Daftar Pustaka}

[1] X. Liu, K.-F. Chung, H.-C. Ho, M. Xiao, Z.-X. Hou, and D. A. Nethercot, "Mechanical behavior of high strength S690-QT steel welded sections with various heat input energy," Eng. Struct., vol. 175, pp. 245-256, 2018.

[2] H. Cerjak, O. Caliskanoglu, N. Enzinger, G. Figner, and M. Pudar, "Increasing of toughness of brittle type S690 HSS weld metal by application of reversible temper embrittlement (RTE)," Weld. World, vol. 61, no. 1, pp. 75-79, 2017.

[3] R. Lacalle et al., "Influence of the Flame Straightening Process on Microstructural, Mechanical and Fracture Properties of S235 JR, S460 ML and S690 QL Structural Steels," Exp. Mech., vol. 53, no. 6, pp. 893-909, 2013.

[4] L. Tuz, "Evaluation of Microstructure and Selected Mechanical Properties of Laser Beal Welded S690QL High-Strength Steel," Adv. Mater. Sci., vol. 18, no. 3, pp. 34-42, 2018.

[5] M. S. Zhao, S. P. Chiew, and C. K. Lee, "Post weld heat treatment for high strength steel welded connections," J. Constr. Steel Res., vol. 122, pp. 167-177, 2016.

[6] A. Sharma, D. Kant Verma, and S. Kumaran, "Effect of post weld heat treatment on microstructure and mechanical properties of Hot Wire GTA welded joints of SA213 T91 steel," Mater. Today Proc., vol. 5, no. 2, Part 2, pp. 8049-8056, 2018.

[7] European Structural Steel Standard, EN 10025: 2004 Part 2- Technical delivery conditions for non-alloy structural steels. .

[8] European Structural Steel Standard, EN 10025: 2004 Part 6- Technical delivery conditions for flat products of high yield strength structural steels in the quenched and tempered condition. .

[9] ASTM E18:2016 Standard Test Methods for 
Rockwell Hardness of Metallic Materials. .

[10] ASTM E407:2007 Standard Practice for Microetching Metals and Alloys. .

[11] A. F. Ireti, A. E. Omeiza, K. M. Oluwasegun, I. D. Adeyemi, O. A. Adewale, and E. Gnozi, "Comparision of Imagej Analysis of Structure of Two Constructional Steel,” Am. J. Engineeding Appl. Sci., vol. 11, no. 1, pp. 318-326, 2018.

[12] ASTM A370:2016 Standard Test Methods and Definitions for Mechanical Testing of Steel Products. .

[13] S. P. Chiew, M. S. Zhao, and C. K. Lee, "Mechanical properties of heat-treated high strength steel under fire/post-fire conditions," J. Constr. Steel Res., vol. 98, pp. 12-19, Jul. 2014. 